\title{
BIOBRIKET DARI CANGKANG KELAPA SEBAGAI ENERGI ALTERNATIF
}

\section{BIOBRIQUETTE FROM COCONUT SHELL TO ALTERNATIVE ENERGY}

\author{
Indah Pratiwi ${ }^{1)}$ \\ ${ }^{1)}$ Program Studi Teknik Analisis Laboratorium Migas Politeknik Akamigas Palembang, 30257, Indonesia \\ Corresponding Author E-mail: indahpratiwikimia@gmail.com
}

\begin{abstract}
Energy is one of the important aspects that can affect various sectors of human life. Savings on fossil fuels can be achieved by developing renewable energy such as biobriquette. Charcoal briquettes made from coconut shells are a form of renewable energy that is feasible to be developed in Indonesia. the quality of the briquettes produced in accordance with existing standards, namely water content $0.6105 \%$ ash content of $875 \mathrm{~kg} / \mathrm{m}^{3}$ and a flame of 0.397 $\mathrm{mgNaOH} / \mathrm{g}$.
\end{abstract}

Keywords: Biobriquette, Adhesives, Water content, Ash content, Flame Test

Abstrak: Energi merupakan salah satu aspek penting yang dapat berpengaruh pada berbagai sektor kehidupan manusia. Penghematan bahan bakar fosil dapat dicapai dengan mengembangkan energi terbarukan seperti biobriket. Briket arang yang terbuat dari cangkang kelapa merupakan salah bentuk energi terbarukan yang layak dikembangkan di Indonesia. kualitas briket yang dihasilkan sesuai dengan standar yang ada, yaitu kadar air 0,6105\%, kadar Abu 875 $\mathrm{kg} / \mathrm{m}^{3}$ dan nyala api 0,397 $\mathrm{mgNaOH} / \mathrm{g}$.

Kata kunci : Biobriket, Perekat,Kadar Air, Kadar Abu, Uji Nyala.

\section{PENDAHULUAN}

Kelangkaan bahan bakar minyak, yang disebabkan oleh kenaikan harga minyak dunia yang signifikan, telah mendorong pemerintah untuk mengajak masyarakat mengatasi masalah energi bersama-sama. Belum lagi dengan terus meningkatnya harga minyak dunia, dimana pemerintah, khususnya Indonesia tidak mungkin terus menerus menambah APBN untuk subsidi bahan bakar minyak. Padahal kita ketahui minyak bumi adalah sumber energi yang tidak terbarukan dan dalam pemanfaatanya berpotensi mengeluarkan gas efek rumah kaca yang dapat memperburuk keseimbangan bumi ini.

Keuntungan pemakaian briket arang antara lain, biayanya lebih murah dibandingkan dengan minyak atau arang kayu, briket arang memiliki masa bakar yang jauh lebih lama, penggunaan briket relatif lebih aman, briket mudah disimpan dan dipindahpindahkan, tidak perlu berkali-kali mengipasi atau menambah dengan bahan bakar yang baru. Dengan berbagai keunggulan tersebut, peran briket arang sebagai bahan bakar alternatif telah diakui di berbagai negara. Sejak tahun 2003 tercatat permintaan briket arang di Sulawesi Tengah dari salah satu perusahaan eksportir adalah sebesar 1.800 ton per tahun. Secara keseluruhan ekspor arang briket tahun 2003 mencapai 26.360,6 ton dengan nilai US\$ 4.699.147 . Tujuan dari penelitian ini adalah untuk mengetahui kadar air, kadar abu dan lama nyala api pada bioebriket cangkang kelapa sesuai Standar Nasional Indonesia.

\section{TEORI DASAR}

\subsection{Briket}

Briket adalah bahan bakar padat yang dapat digunakan scbagai sumber energi alternatif yang mompunyai bentuk tertentu. Beberapa tipe/ bentuk briket yang umum dikenai, antara lain: bantal (oval), sarang tawon (honey comb), silinder (cylinder), telur (egg) dan Iain-lain. Briket dapat dibual dari bermacam-macam bahan baku, seperti ampas tebu, sekam padi, serbuk gergaji. Bahan utama yang harus terdapat dalam bahan baku adaiah selulosa. Semakin tinggi kandungan selulosa semakin baik kualitas briket, briket yang mengandung zat terbang yang terlalu tinggi cenderung mengeluarkan asap dan berbau tidak sedap. Untuk merekatkan 
partikel-partikel zat dalam balian baku pada proses pembuatan briket maka diperlukan zat pcngikat sehingga dihasilkan briket yang kompak.

Pembriketan adalah proses pengolahan yang mengalami perlakuan penggerusan, pencampuran bahan baku, pencetakan dan penggilingan pada kondisi tertentu sehingga diperoleh briket yang mempunyai bentuk, ukuran fisik, dan sifat kimia tertentu. Tujuan dari pembriketan adaiah untuk meningkatkan kualitas bahan bakar, kemudahan penanganan transportasi serta mengurangi kehilangan bahan dalam bentuk debu pada proses pcngangkutan. Faktor - faktor yang mempengaruhi pembriketan adalah ukuran dan distribusi partikel, kekerasan bahan dan sifat elastisitas bahan dan plastisitas bahan (Sutiyono, 2008). Syarat briket yang baik adalah briket yang permukaanya halus dan tidak meninggalkan bekas hitam di tangan.

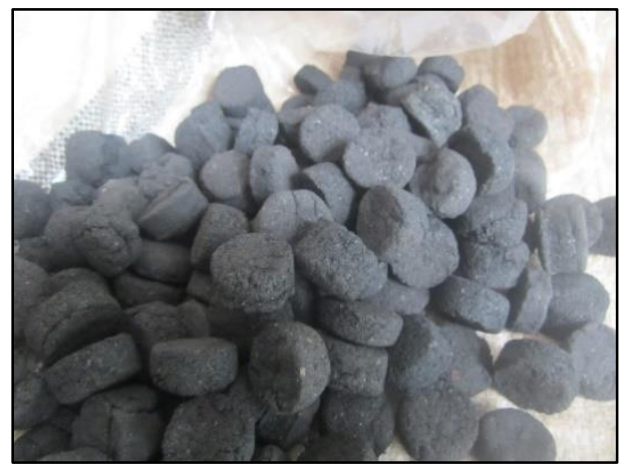

Sumber: Sutiyono,2008

Gambar 2.1 Briket

Selain itu, sebagai bahan bakar, briket juga harus memenuhi kriteria sebagai berikut:

1. Mudah dinyalakan

2. Tidak mengeluarkan asap

3. Emisi gas hasil pembakaran tidak mengandung racun

4. Kedap air dan hasil pembakaran tidak berjamur bila disimpan pada waklu lama.

5. Menunjukkan upaya laju pembakaran (waktu, laju pembakaran, dan suhu pembakaran) yang baik.

\subsection{Cangkang Kelapa}

Indonesia memiliki perkebunan kelapa terluas di dunia. Kelapa yang harus dipangkas setiap tahunnya mencapai 8,6 ton per hektar kebun, dan saat ini sebagian besar belum dimanfaatkan. Salah satu pemanfaatan yang potensial adalah menjadikannya sebagai sumber energi biomassa. Cangkang kelapa dapat diperoleh sepanjang tahun bersamaan panen tandan buah segar. Cangkang kelapa dipanen 1 - 2 pelepah/panen/pohon. Setiap tahun dapat menghasilkan 22 - 26 kelapa/ tahun dengan rataan berat cangkang 4- 6 $\mathrm{kg} / \mathrm{kelapa}$, bahkan produksi kelapa dapat mencapai 40 - 50 pelepah/pohon/tahun dengan berat sebesar $4,5 \mathrm{~kg} /$ cangkang .

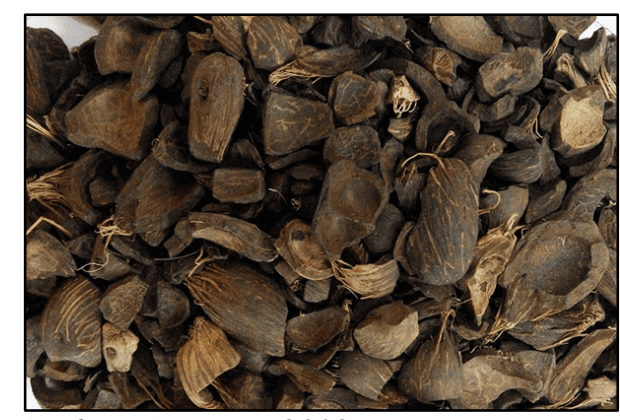

Sumber: Sutiyono, 2008

Gambar 2.2 Cangkang Kelapa

Salah satu limbah perkebunan yang dapat dimanfaatkan adalah daun kelapa yang berasal dari pemangkasan pelepah daun kelapa sawit. Dari satu pelepah daun kelapa sawit dapat dihasilkan 3,333 $\mathrm{kg}$ daun kelapa sawit segar dengan kandungan bahan kering mencapai $35 \%$. Susunan daun tanaman kelapa mirip dengan tanaman kelapa, yaitu membentuk susunan daun mejemuk. Daundaun tersebut akan membentuk suatu buah dan pohonnya yang panjangnya dapat mencapai kurang.

\section{METODOLOGI PENELITIAN 3.1 Alat dan Bahan}

Alat yang digunakan ialah furnace, timbangan, ayakan, palu, beaker glass, batang pengaduk, oven, palu, alu dan mortar.

Bahan baku yang digunakan dalam percobaan ini adalah batok kelapa yang didapatkan dari pengepul kelapa di pasar Keputih serta tepung kanji yang akan digunakan sebagai perekat. 


\subsection{Langkah-langkah Percobaan}

Metode percobaan ini diawali dengan menyiapkan tempurung kelapa yang kemudian dihancurkan dengan palu. Kemudian menyiapkan furnace, lalu memasukkan pecahan tempurung kelapa ke dalam furnace dan mengatur suhu $450{ }^{\circ} \mathrm{C}$ selama 1 jam. Kemudian haluskan hasil pembakaran menggunakan alu dan mortar. Setelah itu, ayak dan timbang sebanyak 45 gram. Lalu buat perekat menggunakan tepung kanji dan air dengan konsentrasi 40.000 ppm dalam 100\%, panaskan sambil diaduk. Setelah itu, campur perekat dengan hasil ayakan tempurung kelapa. Kemudian cetak hasil campuran tersebut menggunakan cetakan briket. Masukkan briket ke dalam oven dengan suhu $100-105^{\circ} \mathrm{C}$ hingga berat briket konstan.

1. Kadar abu

Prosedur dalam analisa kadar abu, yaitu menimbang 5 gram sampel dan mesukkan ke dalam cawan porselen, kemudian memanaskan sampel hingga menjadi arang dan tidak mengeluarkan asap. Kemudian abukan dalam tanur pada suhu $60{ }^{\circ} \mathrm{C}$ hingga menjadi abu. Lalu dinginkan dalam desikator dan timbang. Untuk menghitung kadar abu digunakan persamaan berikut (Routledge, 2012):

Kadar abu (\%)

$$
=\frac{\text { Berat abu (gr) }}{\text { Berat sampel (gr) }} \times 100 \%
$$

\section{Kadar air}

Prosedur dalam Analisa kadar air yaitu menimbang 1 gram briket kemudian ditelakkan dalam cawan kemudian dimasukkan ke dalam oven dengan suhu $105^{\circ} \mathrm{C}$ selama 3 jam. Dinginkan dalam desikator dan ditimbang. Panaskan briket yang sudah ditimbang selama 30 menit. Dinginkan dalam desikator dan ditimbang hingga didapatkan berat konstan dari briket. Untuk menghitung kadar air digunakan persamaan berikut (Routledge, 2012):

\section{Uji nyala api}

$$
\% \text { Kadar air }=\frac{b-c}{b-a} \times 100 \% .
$$

Prosedur dalam Analisa uji nyala api, yaitu menyalakan briket hingga menjadi abu kemudian menghitung waktu yang dibutuhkan briket dari nyala hingga menjadi abu.

\section{HASIL DAN PEMBAHASAN}

Bahan baku yang digunakan dalam percobaan ini ialah tempurung kelapa yang didapat dari pengepul kelapa di pasar Variable yang digunakan dalam percobaan ini adalah suhu dan waktu pembakaran serta konsentrasi perekat. Metode percobaan ini diawali dengan menyiapkan tempurung kelapa yang kemudian dihancurkan dengan palu. Kemudian menyiapkan furnace, lalu memasukkan pecahan tempurung kelapa ke dalam furnace dan mengatur suhu $450^{\circ} \mathrm{C}$ selama 1 jam. Kemudian haluskan hasil pembakaran menggunakan alu dan mortar setelah itu ayak dan timbang sebanyak 45 gram. Lalu buat perekat menggunakan tepung kanji dan air dengan konsentrasi 40.000 ppm dalam 100\%, panaskan sambil diaduk. Setelah itu, campur perekat dengan hasil ayakan cangkang kelapa. Kemudian cetak hasil campuran tersebut menggunakan cetakan briket. Masukkan briket ke dalam oven dengan suhu $100-105{ }^{\circ} \mathrm{C}$ hingga berat briket konstan. Tujuan dari percobaan ini adalah terdapat 3 analisa pada percobaan ini meliputi analisa kadar abu dan kadar air serta uji nyala api.

\subsection{Uji Kualitas Biobriket}

Uji biobriket meliputi Analisa kadar abu dan kadar air, serta uji nyala api.

Tabel 4.1 Hasil Percobaan

\begin{tabular}{|c|l|c|c|}
\hline No. & Parameter & $\begin{array}{c}\text { Hasil } \\
\text { Percobaan }\end{array}$ & $\begin{array}{c}\text { SNI } \\
7182: 2015\end{array}$ \\
\hline 1 & Kadar Abu & $875 \mathrm{~kg} / \mathrm{m}^{3}$ & $850-890$ \\
\hline 2 & Kadar Air & 0,6105 & $\begin{array}{c}2,3-6,0 \\
\mathrm{~mm}^{2} / \mathrm{s}(\mathrm{cSt})\end{array}$ \\
\hline 3 & Nyala Api & $\begin{array}{c}0,397 \\
\mathrm{mgNaOH} / \mathrm{g}\end{array}$ & Maks $0,5 \mathrm{mg}$ \\
\hline
\end{tabular}

Tabel 4.2 Spesifikasi Persyaratan Mutu Briket Arang Kayu 2018

\begin{tabular}{|c|l|c|c|}
\hline No. & \multicolumn{1}{|c|}{ Parameter } & Satuan & Persyaratan \\
\hline 1 & Kadar Air b/b & $\%$ & Maksimum 8 \\
\hline 2 & $\begin{array}{l}\text { Bagian yang } \\
\text { hilang pada } \\
\text { pemanasan } \\
90^{\circ} \mathrm{C}\end{array}$ & $\%$ & Maksimum 15 \\
\hline 3 & Kadar Abu & $\%$ & Maksimum 8 \\
\hline 4. & Kalori & $\mathrm{kal} / \mathrm{g}$ & Minimum \\
\hline
\end{tabular}




\begin{tabular}{|c|c|c|c|}
\hline No. & Parameter & Satuan & Persyaratan \\
\hline & $($ ADBK $)$ & & 5000 \\
\hline
\end{tabular}

\section{KESIMPULAN DAN SARAN}

\subsection{Kesimpulan}

Dari penelitian yang sudah dilakukan, maka dapat disimpulkan sebagai berikut:

1. Cangkang kelapa sawit dapat ditingkatkan nilai ekonomisnya dengan cara dibuat briket.

2. Bioriket arang yang dihasilkan dari bahan baku cangkang kelapa sawit dapat dijadikan alternatif bahan bakar karena kualitas briket yang dihasilkan sesuai dengan standar yang ada, yaitu kadar air 0,6105 \% (SNI : < 8\%), kadar abu 875 $\mathrm{kg} / \mathrm{m}^{3}\left(\mathrm{SNI}:<890 \mathrm{~kg} / \mathrm{m}^{3}\right)$ dan nyala api 0,397 $\mathrm{mgNaOH} / \mathrm{g}$ (SNI: Maks 0,5 mg)

\section{DAFTAR PUSTAKA}

Routledge. 2012. Beyond De-foaming: The Effects of Antifoams on Bioprocess Productivity. Computational and Structural Biotechnology Journal, Vol. 3 No. 4.

Angara. 2014. Pengertian Kelapa Sawit Dan Komposisinya.

http://www.sharemyeyes.com/2013/10/tempur ung-kelapa.html.

Sahar, et.al. 2018. Biodiesel Production from Waste Cooking Oil: An Efficient Technique to Convert Waste into Biodiesel. Sustainable Cities and Society. 220-226.

Sutiyono. 2008. Pembuatan Briket Arang dari Tempurung Kelapa dengan Bahan Pengikat Tetes Tebu dan Tapioka. Palembang.

Schramm, L.L., 2005. Emulsion, Foams, and Suspensions. 47-49, 141-142, Wiley-VCH Verlag GmbH \& Co. KGaA, Weinheim. 
